

\title{
Parque Augusta: disputas em torno do espaço público em São Paulo.
}

\section{Beatriz C. Lacerda*}

\section{Resumo}

O objetivo deste projeto de pesquisa é tendo como foco a mobilização em torno do Parque Augusta na cidade de São Paulo - cuja existência está ameaçada enquanto espaço público - entender as tensões da negociação sobre o espaço da cidade, a privação de espaços verdes na metrópole e o protagonismo da arte em questões urbanas.

\section{Palavras-chave}

Espaço público, urbanismo, arte urbana.

\section{Introdução}

A partir do embate no caso do Parque Augusta, esta pesquisa procura entender a cidade não só como espaço geográfico em que habitamos e construímos, mas também como um espaço soberano, ao que nós, agentes interventores, devemos inovar em criatividade de adequação, tendo em vista que é possível modificar sem a completa devastação do meio ambiente e aprendendo a lidar com as diversas formas de gestão dessa urbanidade, movida ora pelo interesse público, simbolizado na comunidade, ora pelo capital, simbolizado na especulação imobiliária.

É importante salientar a presença da arte trazendo uma força mais do que simbólica, real, para as atuações políticas. A ocupação do Parque Augusta foi espaço de intensa troca artística, laboratório para experimentos independentes e espaço para coletivos já existentes. Houve Vigília Criativa, Guerrilha Artística e outras produções políticas-culturais.

\section{Resultados e Discussão}

Parque Augusta a cada dia se reafirma como um símbolo de disputa entre a função social da propriedade e da terra urbana, contra a lógica da propriedade privada e sua herança colonial, exploratória, patriarcal e escravocrata.

A estratégia hoje então é a Ação Imediata para finalizar de vez as tentativas de destruição desse território afetivo comunitário e permitir o retorno do acesso da população para construção e gestão desse novo-velho parque da cidade. Ação imediata para libertar esse território que não pode ser valorado, ao menos pelas medidas hoje impostas pela nossa sociedade em tempos de um capitalismo tardio.

\section{Conclusões}

Com este estudo, torna-se próxima a compreensão das maneiras pelas quais as cidades são administradas, quem são seus dirigentes, como se dá essa direção, além de chamar a atenção para a carência de áreas verdes em São Paulo e para a atuação dos órgãos responsáveis pela expansão urbana, no que diz respeito, por exemplo, ao Plano Diretor para por fim, aprofundar a relação entre realidade e utopia.

\section{Agradecimentos}

Agradecimentos ao PIBIC - UNICAMP. 